\title{
Adult diagnosis of Cockayne syndrome
}

Antoniangela Cocco, MD, Daniela Calandrella, MD, Miryam Carecchio, MD, PhD, Barbara Garavaglia, PhD, and Alberto Albanese, MD

Neurology ${ }^{\circledR}$ 2019;93:854-855. doi:10.1212/WNL.0000000000008449

Figure Axial T2-weighted MRI and axial CT scan

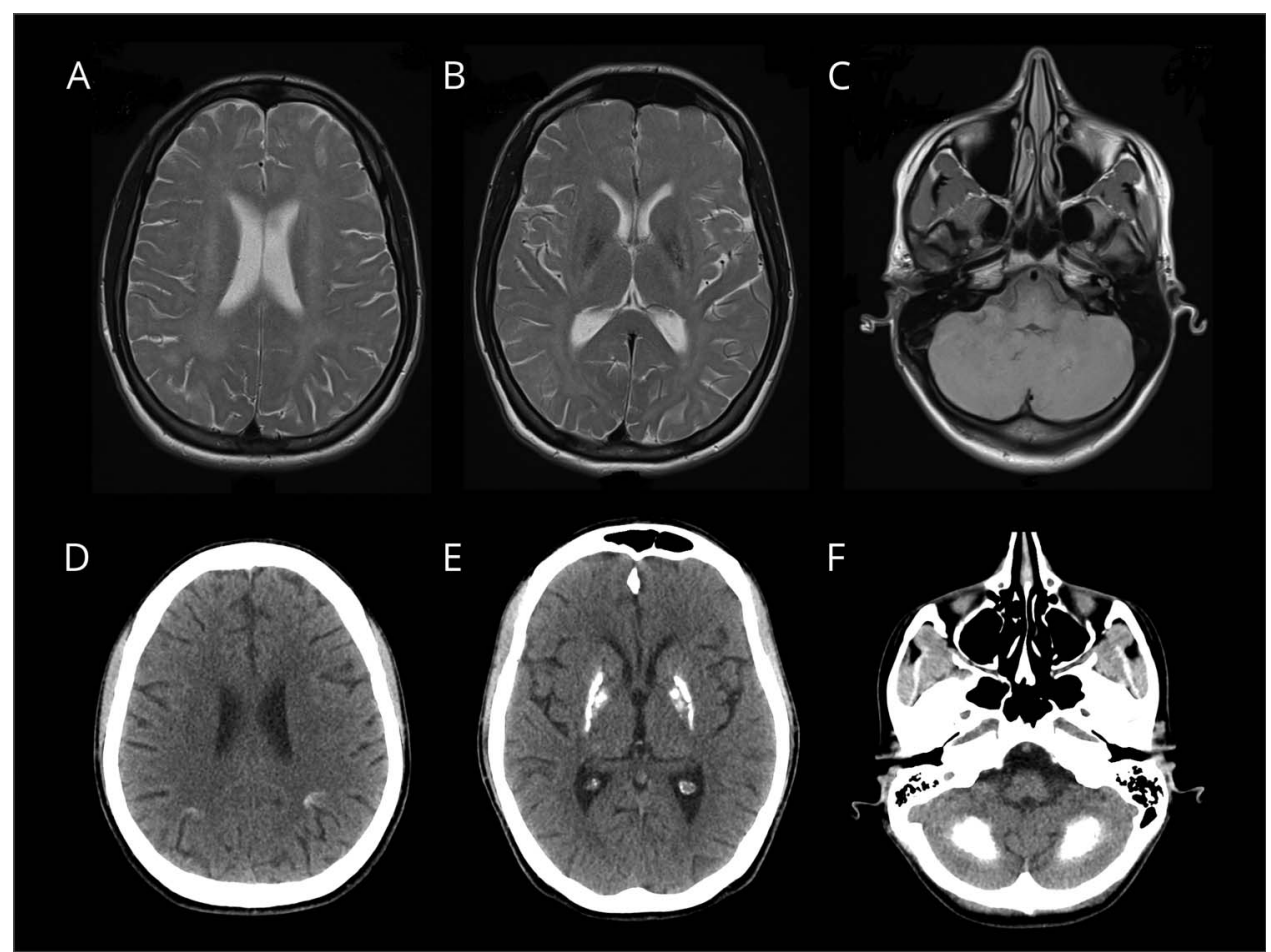

Axial T2-weighted MRI (A-C) shows white matter abnormalities and brain calcifications. Axial CT scan (D-F) demonstrates calcifications in the cortical sulci, basal ganglia, and cerebellum.

A 20-year-old woman presented with bilateral upper limb tremor, mild dystonia, and dysphonia (video). She had dermal photosensitivity, crowded facial features, short stature, and mild intellectual disability. Family history was unremarkable. Brain MRI and CT scan revealed subcortical white matter abnormalities and calcifications in the cortical sulci, basal ganglia, and cerebellum (figure). Genetic testing confirmed a Cockayne syndrome B with biallelic heterozygous mutations in the ERCC6 gene (p.Gly715* in exon 10, p.Arg77*in exon 2). Cockayne syndrome should be suspected in adult patients when radiologic and clinical findings are consistent. ${ }^{1,2}$

\section{Author contributions}

A. Cocco: prepared the manuscript, images, and video. D. Calandrella: prepared the manuscript. M. Carecchio: critically revised the manuscript. B. Garavaglia: performed genetic analysis. A. Albanese: critically revised the manuscript and the video.
Correspondence

Dr. Cocco

antoniangela.cocco@

gmail.com
MORE ONLINE

- Video

From the Department of Neurology (A.C., D.C., A.A.), IRCCS Humanitas Research Hospital and University, Rozzano, Milan; Department of Neuroscience (M.C.), University of Padua; Medical Genetics and Neurogenetics Unit (B.G.), IRCCS Carlo Besta Neurological Institute; and Department of Neurology (A.A.), Catholic University, Milan, Italy.

Go to Neurology.org/N for full disclosures. Funding information and disclosures deemed relevant by the authors, if any, are provided at the end of the article. 


\section{Study funding}

No targeted funding reported.

\section{Disclosure}

The authors report no disclosures relevant to the manuscript.

Go to Neurology.org/N for full disclosures.

\section{References}

1. Wilson BT, Stark Z, Sutton RE, et al. The Cockayne Syndrome Natural History (CoSyNH) study: clinical findings in 102 individuals and recommendations for care. Genet Med 2016;18:483-493.

2. Koob M, Laugel V, Durand M, et al. Neuroimaging in Cockayne syndrome. AJNR Am J Neuroradiol 2010;31:1623-1630.

\section{Subspecialty Alerts by E-mail!}

Customize your online journal experience by signing up for e-mail alerts related to your subspecialty or area of interest. Access this free service by clicking on the "My Alerts" link on the home page. An extensive list of subspecialties, methods, and study design choices will be available for you to choose from-allowing you priority alerts to cutting-edge research in your field!

\section{Apply for 2020 Live Well, Lead Well Programs by November 29}

There's still time to help build a community of wellness leaders by applying for one of two unique well-being and resiliencecultivating programs in conjunction with the 2020 Annual Meeting in Toronto: Live Well, Lead Well: Improve Your Practice Culture or Live Well, Lead Well: Influence Your Program. Visit AAN.com/view/lwlw to apply before November 29-and encourage a colleague who is interested in being a well-being champion to apply, too!

\section{New AAN Practice Management Webinar Format Digs Deeper}

The new format offers a live, 30- to 45-minute webinar with expert faculty followed by several shorter recorded online lectures that explore the topic in greater depth. Each topic concludes with a 30-minute live webchat for further participant Q\&A. Purchase a single webinar series for $\$ 99$ or purchase a 2019 Practice Management Webinar subscription for only \$189_that's less than $\$ 32$ per webinar!

\section{Webinar Series}

- January 15 - Boss, MD: Managing a Better Practice

- March 12 - Understanding How You Get Paid

- May 21 - Everything You Wanted to Know About Your Patients but Were Afraid to Ask: Having Difficult Conversations with Patients from Vulnerable Populations

- August 13 - Increasing Revenue in Your Practice: Care Models, Ancillary Services, and Other Strategies

- October 1 - Using Technology for Better Practice Management of Stroke

- November 19 - Seeing the Future Clearly: How to Succeed in 2020

Learn more and register at AAN.com/view/webinar. 


\title{
Neurology
}

\author{
Adult diagnosis of Cockayne syndrome \\ Antoniangela Cocco, Daniela Calandrella, Miryam Carecchio, et al. \\ Neurology 2019;93;854-855 \\ DOI 10.1212/WNL.0000000000008449
}

This information is current as of November 4, 2019

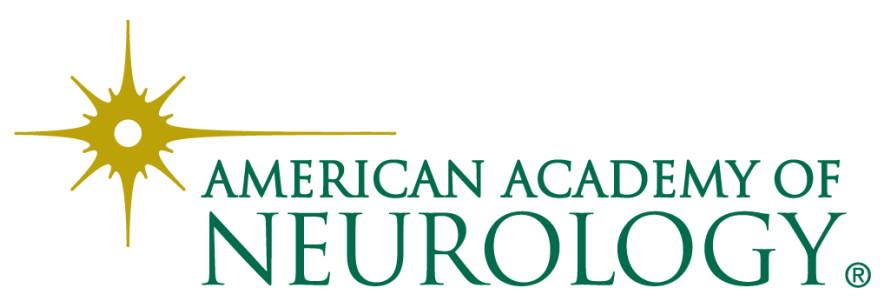




\section{Updated Information \& Services}

\section{References}

Citations

Subspecialty Collections

\section{Errata}

Permissions \& Licensing

\section{Reprints}

including high resolution figures, can be found at: http://n.neurology.org/content/93/19/854.full

This article cites 2 articles, 1 of which you can access for free at: http://n.neurology.org/content/93/19/854.full\#ref-list-1

This article has been cited by 1 HighWire-hosted articles: http://n.neurology.org/content/93/19/854.full\#\#otherarticles

This article, along with others on similar topics, appears in the following collection(s):

\section{All Genetics}

http://n.neurology.org/cgi/collection/all_genetics All Imaging

http://n.neurology.org/cgi/collection/all_imaging

Dystonia

http://n.neurology.org/cgi/collection/dystonia

Mental retardation

http://n.neurology.org/cgi/collection/mental_retardation

Tremor

http://n.neurology.org/cgi/collection/tremor

An erratum has been published regarding this article. Please see next page or:

/content/95/17/802.1.full.pdf

Information about reproducing this article in parts (figures,tables) or in its entirety can be found online at:

http://www.neurology.org/about/about_the_journal\#permissions

Information about ordering reprints can be found online:

http://n.neurology.org/subscribers/advertise

Neurology ${ }^{\circledR}$ is the official journal of the American Academy of Neurology. Published continuously since 1951, it is now a weekly with 48 issues per year. Copyright @ 2019 American Academy of Neurology. All rights reserved. Print ISSN: 0028-3878. Online ISSN: 1526-632X.

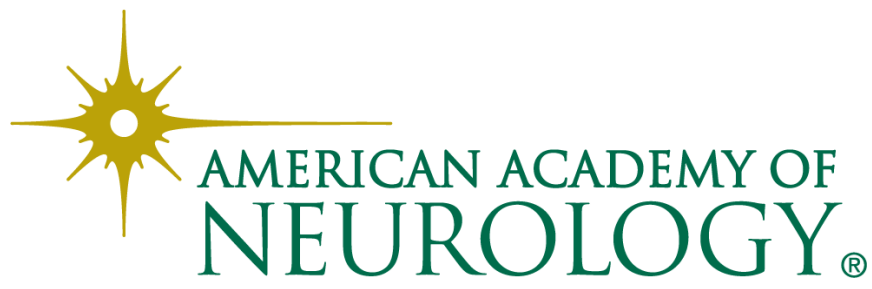




\section{Adult diagnosis of Cockayne syndrome \\ Neurolog ${ }^{\circledR}$ 2020;95:802. doi:10.1212/WNL.0000000000008878}

In the Video NeuroImage article "Adult diagnosis of Cockayne syndrome" by Cocco et al., the figure title should be "Axial T2-and T1-weighted MRI and axial CT scan" and its legend should read "Axial T2-weighted (A-B) and T1-weighted (C) MRI show white matter abnormalities and brain calcifications. Axial CT scan (D-F) demonstrates calcifications in the cortical sulci, basal ganglia, and cerebellum." The publisher regrets the errors.

\section{Reference}

1. Cocco A, Calandrella D, Carecchio M, Garavaglia B, Albanese A. Adult diagnosis of Cockayne syndrome. Neurology 2019;93:854-855.

\section{Determination of death by neurologic criteria around the world} Neurology ${ }^{\circledR}$ 2020;95:802. doi:10.1212/WNL.0000000000010541

In the article "Determination of death by neurologic criteria around the world" by A. Lewis et al., ${ }^{1}$ first published online June 23, 2020, the following names included in the "Acknowledgment" section should appear as: Abualia, Mohammad (Jordan); Abulhasan, Yasser (Kuwait); and Mejia-Mantilla, Jorge (Colombia). The names appear correctly in the July 21, 2020, issue. The authors regret these errors.

\section{Reference}

1. Lewis A, Bakkar A, Krieger-Benson E, et al. Determination of death by neurologic criteria around the world. Neurology 2020;95: e299-e309.

\section{Frequency and risk factors of antibody-induced secondary failure of botulinum neurotoxin therapy}

Neurology ${ }^{\circledR}$ 2020;95:802. doi:10.1212/WNL.0000000000010543

In the short form of the article "Frequency and risk factors of antibody-induced secondary failure of botulinum neurotoxin therapy" by U. Walter et al., ${ }^{1}$ the final sentence under subheading "Main results and the role of chance" should read "NAB-induced complete STF did not occur in patients treated exclusively with incobotulinumtoxinA." The editors and authors regret the error.

\section{Reference}

1. Walter U, Mühlenhoff C, Benecke R, et al. Frequency and risk factors of antibody-induced secondary failure of botulinum neurotoxin therapy. Neurology 2020;94:e2109-e2120. 